\title{
Plant growth-promoting activity of endophytic bacteria from sweet sorghum (Sorghum bicolor (L.) Moench)
}

\author{
Charlie Ester de Fretes ${ }^{1, *}$, Donny Widianto ${ }^{2,3}$, Yekti Asih Purwestri ${ }^{2,4}$, Tri Rini Nuringtyas ${ }^{2,4}$ \\ ${ }^{1}$ Research Center for Deep Sea, National Research and Innovation Agency, Jl. Y. Syaranamual, Ambon, Maluku, 97123, Indonesia \\ ${ }^{2}$ Research Center for Biotechnology, Universitas Gadjah Mada, Jl. Teknika Utara, Barek, Yogyakarta, 55281, Indonesia \\ ${ }^{3}$ Department of Microbiology, Faculty of Agriculture, Universitas Gadjah Mada, J. Flora, Bulaksumur, Yogyakarta, 55281, Indonesia \\ ${ }^{4}$ Faculty of Biology, Universitas Gadjah Mada, Jl. Teknika Selatan, Sekip Utara, Yogyakarta, 55281, Indonesia \\ ${ }^{*}$ Corresponding author: char002@brin.go.id
}

SUBMITTED 24 March 2021 REVISED 2 June 2021 ACCEPTED 24 August 2021

\begin{abstract}
Application of high levels of chemical fertilizers for optimal growth of sweet sorghum causes environmental degradation. Plant growth-promoting bacteria have biotechnological importance because they can improve the growth and health of important agronomic plants. This study aimed to isolate, characterize, and identify endophytic bacteria associated with sweet sorghum (cv. KCS105), and also to study the inoculation effects of selected isolates on sorghum growth. In this study, 35 isolates were evaluated for their ability to support plant growth. The results showed that seven isolates were diazotrophic, six were capable of dissolving phosphate, six produced IAA and could detect ACC-deaminase activity, and three inhibited the growth of pathogenic fungi. Nine isolates exhibiting mechanisms for promoting plant growth from the Alphaproteobacteria (Devosia), Firmicutes (Bacillus, Paenibacillus, Staphylococcus), and Actinobacteria (Microbacterium, Brachybacterium) phyla were identified. In addition, the Paenibacillus sp. BB7, Bacillus sp. PIB1B, and Bacillus sp. PLB1B isolates showed increasing effects on plant growth in greenhouse tests. Endophytic bacterial isolates which display plant growth-promoting features can potentially be employed as biofertilizer agents. They may also address environmental damage problems resulting from the use of chemical fertilizers and pesticides.
\end{abstract}

KEYWORDS Endophytic bacteria; plant growth-promoting bacteria; sweet sorghum; 16S rRNA gene

\section{Introduction}

Globally, sweet sorghum is widely utilized for grain production for food, syrup, animal feed, and bioethanol (Almodares and Hadi 2009). However, the increasing demand for sweet sorghum has led to the excessive use of chemical fertilizers, which may cause unavoidable deleterious effects on the environment, including the groundwater. Therefore, innovation in sustainable agricultural technology by employing biological agents for chemical fertilizers and pesticides substitution is required (Pretty and Bharucha 2014).

Most endophytes are microbes that are living in the plant tissue but do not negatively affect the host plant. Some endophytes promote plant growth through plant growth stimulation mechanisms, including providing plants with needed resources/nutrients and modulating plant growth (Santoyo et al. 2016). It has been reported that endophytic bacteria are found in roots, stems, leaves, seeds, fruit, tubers, ovaries, and legume nodules (Hallmann et al. 1997). Several studies have reported that the sweet sorghum has interaction with several endo- phytic bacteria, such as genus Rhizobium, Herbaspirillum, Enterobacter, Paenibacillus, Achromobacter, Ralstonia, Azospirillum, Acinetobacter, Klebsiella, Burkholderia, Pantoea, Pseudomonas, Streptomyces, Staphylococcus, and Chryseobacterium (Grönemeyer et al. 2012; Mareque et al. 2015).

The host plants may benefit from increased growth by nitrogen fixation and phytohormone production and resistance to pathogenic microbes (Compant et al. 2010). In addition, the secondary metabolites produced by endophytic bacteria and rhizobacteria on their host plants affect the physiological development of plants and provide resistance to disease (Afzal et al. 2019). This symbiosis may allow the endophytic bacteria to obtain nutrients from plant metabolism and protect from environmental stresses. Therefore, the endophytic bacteria are better to protect from biotic and abiotic stress than the rhizosphere bacteria (Hallmann et al. 1997).

In this study, the endophytic bacterial were isolated from sweet sorghum KCS 105. Previous research showed that sweet sorghum var. KCS105 grown in dryland farming areas has the highest production of fresh biomass, dry 
biomass, sugar stems, and ethanol compared to other varieties (Gusti et al. 2013). The use of high fertilizers follows the increased productivity of sweet sorghum. Therefore, the determination of biological agents is expected to reduce the use of chemical fertilizers. The previous report showed that the growth of sweet sorghum was significantly increased by the addition of potential bacterial supernatant plus humic acid compared to the use of chemical fertilizers (Afifi et al. 2014). This study aims to obtain endophytic bacteria capable of nitrogen fixation, phosphate dissolution, indole-3-acetic acid (IAA) and ACC-deaminase production, and antagonistic tests against pathogenic fungi so that they can be utilized as biofertilizers.

\section{Materials and Methods}

\subsection{Isolation of endophytic bacteria from sweet sorghum}

In this study, the endophytic bacteria were isolated from the roots, stems, and shoots of sweet sorghum cv. KCS105 and carried out using the improved method of de Fretes et al. (2018). Ten grams of plant parts were sterilized by soaking for $5 \mathrm{~min}$ in $70 \% \mathrm{EtOH}$, then immersed for $20 \mathrm{~min}$ in $4 \%$ sodium hypochlorite solution. Next, the plant material was rinsed four times with sterile deionized water. To ensure that the disinfection process is successful, the final rinse water was spread on Tryptic Soy Agar (TSA) and incubated at $28^{\circ} \mathrm{C}$ for $5 \mathrm{~d}$. The sterilization was considered successful if there was no bacterial growth. The sterilized plant material was macerated aseptically in $0.9 \% \mathrm{NaCl}$ solution and inoculated on TSA medium followed by incubating at $28^{\circ} \mathrm{C}$ for $5 \mathrm{~d}$. The different colonies that grew on the medium were further purified by the quadrant streak technique on the TSA medium. The 50\% glycerol stock from the pure culture of isolates was prepared and stored at $-80{ }^{\circ} \mathrm{C}$ for preservation.

\subsection{Nitrogen fixation ability and detection of nifH gene of endophytic bacteria}

The endophytic bacterial isolates were cultivated on semisolid LGI (N-free medium) at $30{ }^{\circ} \mathrm{C}$ (Mareque et al. 2015). After $7 \mathrm{~d}$ of incubation, observations were made on the formation of membrane/pellicle and color change in the tube as a marker of $\mathrm{N}$ fixation. Isolates that were positive on testing with LGI medium were subjected to test for diazotrophic properties by targeting nifH gene using primers of PolF (5'-TGCGAYCCSAARGCBGACTC-3') and PolR (5'-ATSGCCATCATYTCRCCGGA-3'). The PCR conditions were as follows; one cycle for $5 \mathrm{~min}$ at $95{ }^{\circ} \mathrm{C}$; 30 cycles for $45 \mathrm{~s}$ at $95^{\circ} \mathrm{C}$ for denaturation; for 45 $\mathrm{s}$ at $58^{\circ} \mathrm{C}$ for annealing, for $30 \mathrm{~s}$ at $72{ }^{\circ} \mathrm{C}$ for an extension, and final cycle for $5 \mathrm{~min}$ at $72^{\circ} \mathrm{C}$. The amplification products were analyzed with $1 \%(\mathrm{w} / \mathrm{v})$ electrophoresis agarose gel in TBE buffer and stained with SYBR (Invitrogen).

\subsection{Phosphate solubilization activity of endophytic bacteria}

The phosphate solubility test was conducted by inoculating endophytic bacterial isolates in the Pikovskaya medium. After $72 \mathrm{~h}$ of incubation, observations were made on the growth of the isolates. A clear halo area around the colony would be observed in a medium containing phosphate endophytic isolates.

\subsection{IAA production of endophytic bacteria}

The test for endophytic bacteria in producing IAA was quantitatively tested using the colorimetric method (Jasim et al. 2014b). The isolates were inoculated in a test tube containing $5 \mathrm{~mL}$ of Tryptic Soy Broth (TSB) media containing $1 \mathrm{mg} / \mathrm{mL}$ L-tryptophan at $\mathrm{pH} 7.0$ and were incubated for 24-48 $\mathrm{h}$ at room temperature. Next, the culture was centrifuged at 13,000 rpm for $15 \mathrm{~min}$. As much as $1 \mathrm{~mL}$ of supernatant was mixed with $2 \mathrm{~mL}$ of Salkowski reagent $\left(50 \mathrm{~mL}\right.$ of $35 \% \mathrm{HClO}_{4}$ and $1 \mathrm{~mL}$ of $0.5 \mathrm{M} \mathrm{FeCl}_{3} .6 \mathrm{H}_{2} \mathrm{O}$ solutions). The mixture was allowed to stand for \pm 30 min for color development in a dark environment. The development of pink color indicated the production of IAA. The quantitative analysis of the IAA concentration was carried out using a spectrophotometer at $\lambda 530 \mathrm{~nm}$.

\subsection{ACC deaminase activity of endophytic bacteria}

The test for endophytic bacteria in producing ACC deaminase was carried out by growing the bacteria on LGI + N media for $48 \mathrm{~h}$ (Mareque et al. 2015). Next, the cultures were centrifuged at 10,000 rpm for $20 \mathrm{~min}$. The supernatant was removed, and the pellets were washed twice with LGI media. The washed cells were again suspended in $25 \mathrm{~mL}$ of LGI. As much as $150 \mu \mathrm{L}$ of suspension was inoculated into solid LGI media with addition of $30 \mathrm{mmol}$ of ACC as a nitrogen source. The growing isolated bacteria were considered capable of producing ACC deaminase.

\subsection{Antagonism test against pathogenic fungi}

The antagonism test was conducted using the pathogenic fungus Fusarium. First, the bacterial isolates were grown in TSB media for $24 \mathrm{~h}$ at $28^{\circ} \mathrm{C}$, and the antagonistic activity was evaluated using PDA media. The pathogenic fungi aged $5 \mathrm{~d}$ were taken with a $5 \mathrm{~mm}$ diameter plate, placed in the center of a Petri dish, and incubated for $72 \mathrm{~h}$ at 25 ${ }^{\circ} \mathrm{C}$. Next, the endophytic bacterial isolates were streaked on PDA plates and incubated for $48 \mathrm{~h}$ at $25{ }^{\circ} \mathrm{C}$. The endophytic bacterial isolates that could inhibit pathogenic fungi' growth would form a clear zone around the isolate.

\subsection{Plant growth-promoting activity test of endo- phytic bacteria}

The growth response of sweet sorghum cv. Numbu inoculated with endophytic bacteria was studied under greenhouse conditions. The surface-sterilized seeds were put into Erlenmeyer containing potential endophytic bacterial cultures (OD $600 \mathrm{~nm}=1$ ) and were incubated for $45 \mathrm{~min}$ 
along with slow agitation. The inoculated seeds were germinated in $0.8 \%$ water agar for $2 \mathrm{~d}$, transferred to a singleuse Petri dish $(\varnothing 20 \mathrm{~cm})$ containing $250 \mathrm{~g}$ of sand as a substrate, and maintained in greenhouse conditions with a photoperiod of 8/16 h light/dark. The test had five treatments with six replications in a completely randomized design. The isolates tested as inoculants were Paenibacillus sp. BB7, Bacillus sp. PIB1B, and Bacillus sp. PLB1B. The treatment containing plants without inoculation was used as the negative control. Moreover, the plants inoculated in fertilized media were used as the positive control. At 28 experimental days, the plants were harvested and stem and root lengths were measured. In addition, the plants were dried at $60{ }^{\circ} \mathrm{C}$ to constant weight, then the dry weight was determined.

\subsection{Identification of potential of endophytic bacteria with the sequence of $16 S$ rRNA gene}

The potential endophytic bacteria were cultured in TS medium for $24 \mathrm{~h}$ at room temperature and centrifuged at 11,000 rpm for $5 \mathrm{~min}$. The genomic DNA was extracted from pellets using FavorPrepTM Genomic DNA. The amplification of the 16S rRNA gene was performed with $27 \mathrm{f}$ (5'-AGAGTTTGATCMTGGCTCAG-3') and 1492r (5'TACGGHTACCTTGTTACGACTT-3'). DNA was amplified with the Biorad Thermal Cycler program as follows: denaturation at $94{ }^{\circ} \mathrm{C}$ for $5 \mathrm{~min}, 30$ cycles of denaturation (at $94{ }^{\circ} \mathrm{C}$ for $1 \mathrm{~min}$ ), annealing (at $55^{\circ} \mathrm{C}$ for $45 \mathrm{~s}$ ), and extension (at $68{ }^{\circ} \mathrm{C}$ for $2 \mathrm{~min}$ ) with a final extension at $72{ }^{\circ} \mathrm{C}$ for $10 \mathrm{~min}$. All amplified products were visualized using gel electrophoresis with $1 \%$ agarose in 1x TBE buffer and stained with SYBR. The PCR products were analyzed based on their nitrogen base sequence using BigDye ${ }^{\circledR}$ Terminator v3.1 (1st Base Pte. Ltd, Singapore). The results of the analysis of nitrogen base sequences of the 16S rRNA gene were then used as queries in the BLAST on the NCBI website. The phylogenetic analysis was performed using MEGA X software. The neighbor-joining method was used to construct the phylogenetic tree and the tree reliability was tested using bootstrapping with 1000 replications.

\subsection{Data analysis}

Analysis of variance was performed using SPSS 15 program, where the significant differences at $\mathrm{p}<0.05$ were followed by the Duncan test.

\section{Results and Discussion}

Thirty-five endophytic bacterial isolates were obtained from the roots, stems, and shoots of sweet sorghum cv. KCS105 consisted of 13, 11, and 11 isolates, respectively. Previous studies reported that higher population density and diversity of endophytic were found in plant roots than above-ground tissue and the endophytic bacterial migration would increase from root to leaf (Rosenblueth and Martínez-Romero 2006). It is indicated that the root is the main entry point for endophytic microbes from the

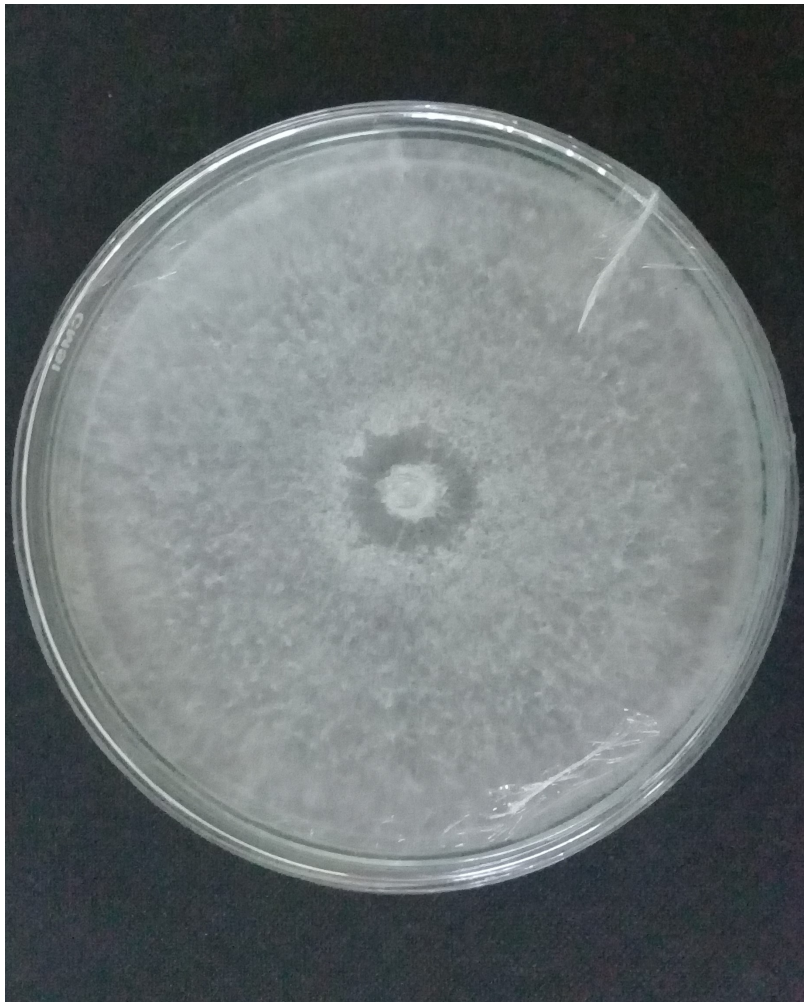

(a)

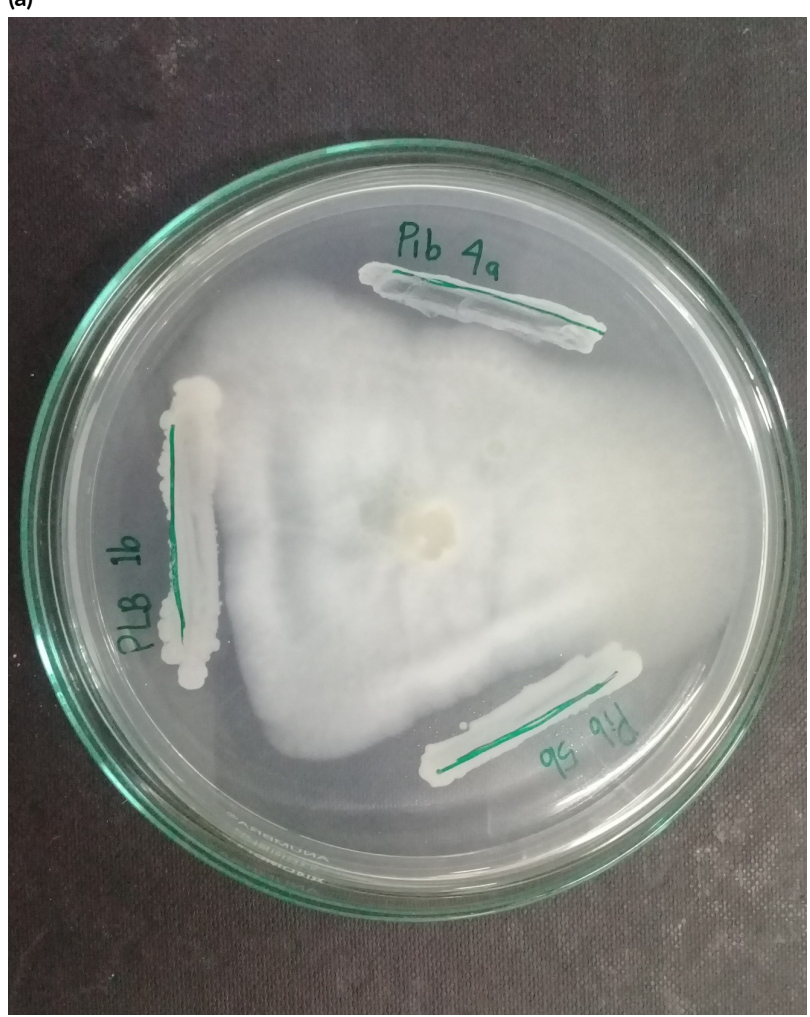

(b)

FIGURE 1 Inhibition of the growth of Fusarium pathogens (a) by endophytic bacteria PIB4A, PIB5B, and PLB1B (b)

soil and their distribution in the tissue above. The microecosystems in the root area are widely recognized as the source of endophytic bacteria colonialization. Moreover, 


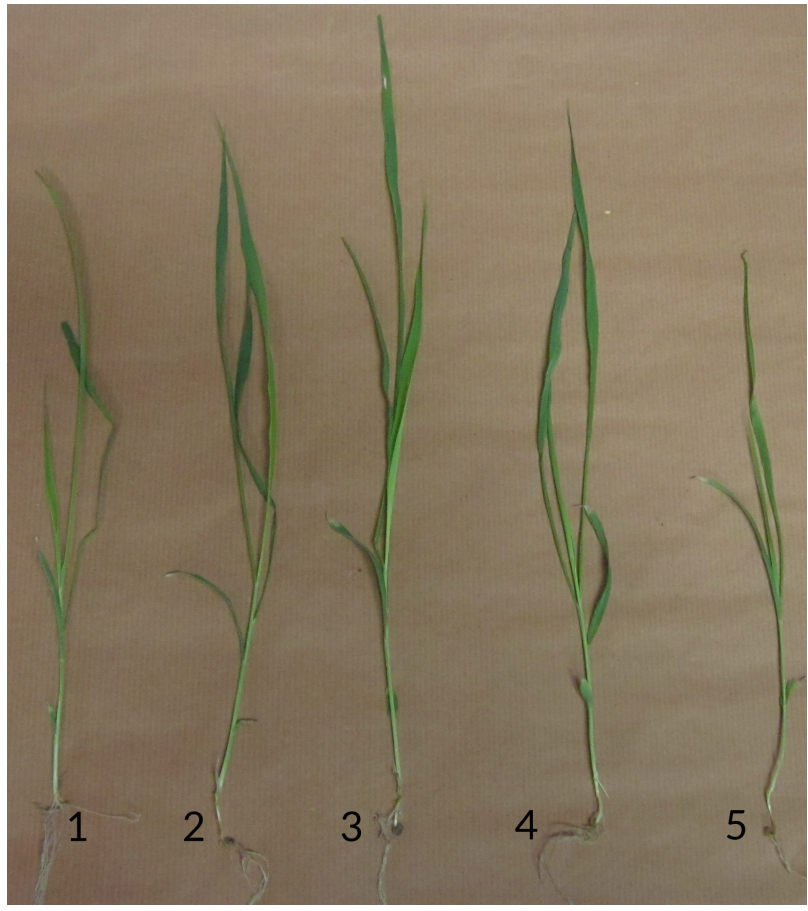

(a)

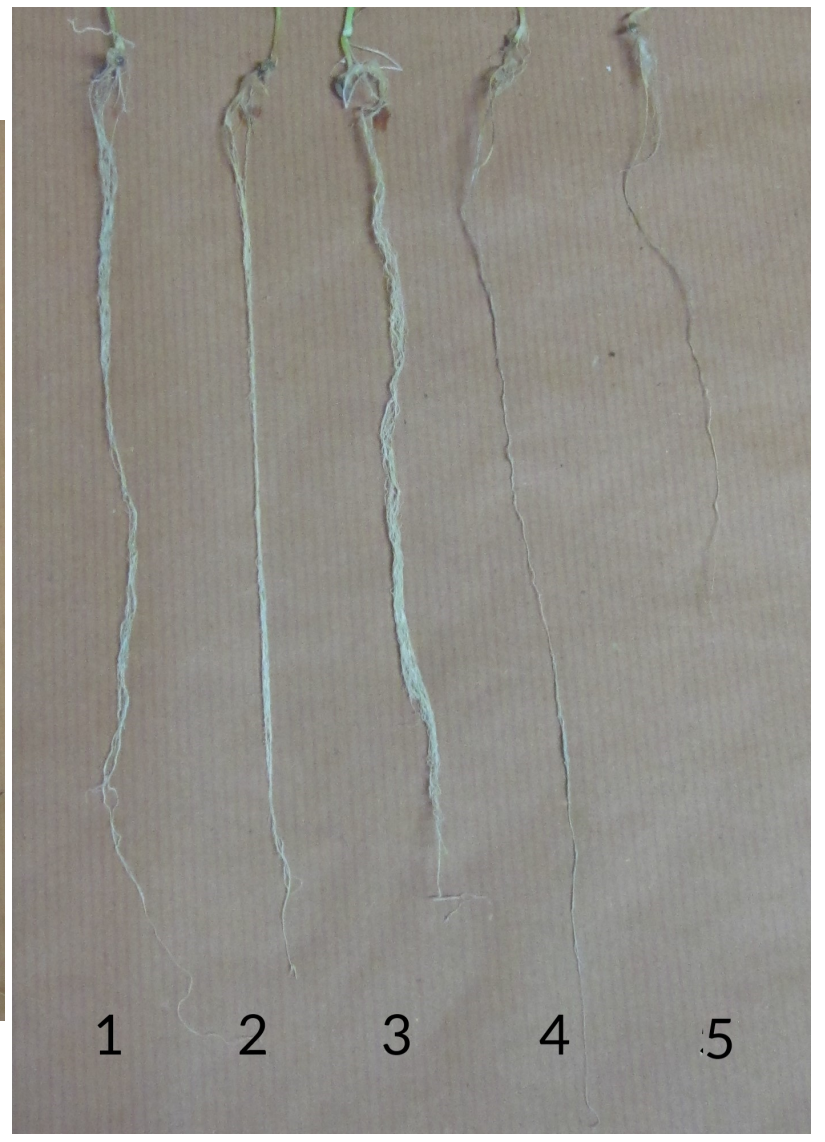

(b)

FIGURE 2 Growth of sweet sorghum cv. Numbu which was inoculated by potential endophytic bacteria after 30 days of planting; 1 . positive control, 2. PIB1B isolates, 3. BB7 isolates, 4. PLB1B isolates, 5. negative control.

the diversity of endophytic bacteria can be thought of as part of the rhizosphere and/or the bacterial population in plant roots (Hallmann et al. 1997).

The ability of endophytic bacteria, a plant growthpromoting bacteria, functions as natural fertilizers were investigated by evaluating the mechanism of plant growthpromoting bacteria indirectly promoting plant growth, including nitrogen fixation, phosphorus dissolving, production of auxins, ACC deaminases, cytokinins, and gibberellins, as well as iron sequestration by siderophore bac- teria. The results in Table 1 indicated that the endophytic bacterial isolates from sweet sorghum display the ability to promote plant growth.

The results demonstrated that of the 35 tested isolates, seven isolates could perform the nitrogen fixation and dissolve phosphate. The nitrogen fixation is catalyzed by the nitrogenase group enzyme, consisting of two proteins, namely MoFe dinitrogenase (EC 1.18.6.1) and Fe nitrogenase reductase (EC 1.19.6.1). The former is encoded by the nifD and nifK genes, while the latter is encoded by the

TABLE 1 Plant growth-promotion features from endophytic bacteria.

\begin{tabular}{|c|c|c|c|c|c|c|c|}
\hline \multirow{2}{*}{ No. } & \multirow{2}{*}{ Isolate } & \multicolumn{2}{|c|}{ Fixation $\mathrm{N}$} & \multirow{2}{*}{ Solubilization $\mathrm{P}$} & \multirow{2}{*}{$\mathrm{IAA}(\mu \mathrm{g} / \mathrm{mL})$} & \multirow{2}{*}{ ACC-deaminase } & \multirow{2}{*}{ Antagonism } \\
\hline & & $\overline{\mathrm{LGI}}$ & nifH & & & & \\
\hline 1 & BB5B & + & + & + & 25,335 & - & - \\
\hline 2 & BB7 & + & + & + & 33,887 & + & - \\
\hline 3 & PIB4A & - & - & - & - & + & + \\
\hline 4 & PIB1B & + & + & + & 28,964 & + & - \\
\hline 5 & PIB5B & + & + & + & 4,182 & + & + \\
\hline 6 & PIB6U & - & - & - & 2,595 & + & - \\
\hline 7 & PLB4A & + & + & + & - & - & - \\
\hline 8 & PLB1B & + & + & + & 16,887 & + & + \\
\hline 9 & PLB22 & + & + & - & - & - & - \\
\hline
\end{tabular}




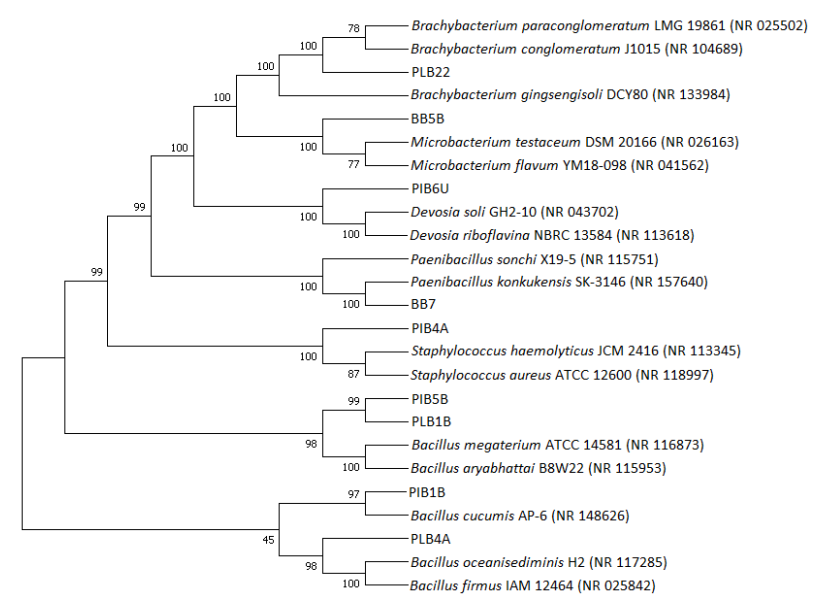

FIGURE 3 Phylogenetic tree based on 16S rRNA sequences of the endophytic bacteria from sweet sorghum cv. KCS105 and other related genera using the neighbor-joining method. Bootstrap values from 1000 replicates are indicated at each node.

nifH gene. Previous studies reported that the nifH gene was detected in isolates of endophytic bacteria from sweet sorghum belonging to the genera Ralstonia, Staphylococcus, Bacillus, Rhizobium, and Paenibacillus. (Mareque et al. 2015). The phosphate dissolution mechanism by endophytic bacteria involves several enzymes, namely C-P lyase, phosphatase, and phytase. However, most of the microbes from the phosphatase family are soluble through the production of organic acids such as ketogluconate, gluconate, lactate, acetate, succinate, tartaric, oxalate, glycolic, and citrate (Behera et al. 2017) The mechanism is affected by the bacterial strain, environmental conditions, plant, and soil conditions (Gupta et al. 2015). The endophytic bacteria of Lysinibacillus fusiformis, Bacillus cereus, and B. megaterium isolated from the ginseng plant also showed high solvent $\mathrm{P}$ activity (Vendan et al. 2010).

As depicted in Table 1, six endophytic isolates can produce 2.595 to $33.887 \mu \mathrm{g} / \mathrm{mL}$ of IAA. Jasim et al. (2014a) reported that the IAA produced by five endophytic bacteria isolated from Piper nigrum averaged $35 \mu \mathrm{g} / \mathrm{mL}$ and could increase if there was the induction of the endophytic IAA biosynthetic pathway by host plant metabolites. The growth of some plants can be promoted when the plants are colonized with endophytic microbes with the ability

TABLE 2 Effect of endophytic bacterial inoculation on the growth of sweet sorghum cv. Numbu.

\begin{tabular}{llll}
\hline Treatment & $\begin{array}{l}\text { Stem length } \\
(\mathrm{cm})^{*}\end{array}$ & $\begin{array}{l}\text { Root length } \\
(\mathrm{cm})^{*}\end{array}$ & $\begin{array}{l}\text { Dry weight } \\
(\mathrm{g})^{*}\end{array}$ \\
\hline Negative control & $24.33^{\mathrm{b}}$ & $14.32^{\mathrm{c}}$ & $0.03 \mathrm{c}$ \\
Isolate BB7 & $34.08^{\mathrm{a}}$ & $24.53^{\mathrm{b}}$ & $0.06^{\mathrm{a}}$ \\
Isolate PIB1B & $30.85^{\mathrm{a}}$ & $22.90^{\mathrm{b}}$ & $0.06^{\mathrm{a}}$ \\
Isolate PLB1B & $31.33^{\mathrm{a}}$ & $15.23^{\mathrm{c}}$ & $0.05^{\mathrm{ab}}$ \\
Positive control & $30.63^{\mathrm{a}}$ & $29.68^{\mathrm{a}}$ & $0.04^{\mathrm{bc}}$
\end{tabular}

${ }^{*}$ Means that two treatments that have different letters have a significant difference with the Duncan test of 0.05 to generate IAA (Jasim et al. 2014b). The synthesis of IAA by microbes in each pathway is highly dependent on tryptophan as the precursor. Several pathways for the IAA biosynthesis by microbes have been reported, including the indole acetamide (IAM), the indole pyruvic acid (IPyA), the indole acetaldoxime (IAOx)/indole acetonitrile (IAN) pathway (Duca et al. 2014), the indole acetaldehyde (IAH) and the tryptamine pathway (Olanrewaju et al. 2017).

All isolates were screened for 1-aminocyclopropane1-carboxylic acid (ACC) deaminase production on LGI media, at which ACC was used as a nitrogen source. Six isolates of endophytic material were found to have ACCdeaminase activity (Table 1). 1-Aminocyclopropane-1carboxylic acid is a direct precursor of ethylene produced by plants. Therefore, the decrease in ACC levels may prevent ethylene-mediated inhibition of plant growth. The ACC deaminase is a multimeric enzyme that converts ACC into $\alpha$-ketobutyrate and ammonia, thereby reducing ethylene levels in the host plant (Sun et al. 2009). Endophytic bacteria with the ability to reside in the host plant can benefit the host by increasing plant growth and reducing stress (Hardoim et al. 2008). Endophytic bacteria from the genus Bacillus and Staphylococcus can produce ACCdeaminase (Mareque et al. 2015; Correa-Galeote et al. 2018).

The results showed that three isolates of sweet sorghum plant-bacteria could inhibit the growth of Fusarium, namely PIB4A, PIB5B, and PLB1B (Figure 1). In general, bacteria possessing antibiotics have compounds that interfere with fungi's morphological or physiological growth. Additionally, several biocontrol bacteria produce enzymes such as cellulase, chitinase, protease, lipase, and $\beta-1,3$ glucanase, which lyse many pathogenic fungi's cell walls (Hayat et al. 2010). The screening of endophytic microbial extract showed a large structural diversity of natural compounds with a broad spectrum of biological activities, such as antiviral, antimicrobial, antitumor, and immunosuppressive activities (Sansinenea and Ortiz 2011). Endophytic bacteria from the Actinobacteria and Bacillus may produce lipopeptides, polysaccharides, aromatic compounds, plant hormones, and several enzymes associated with phenylpropanoid metabolism, thus representing the high potential for PGP and plant management strategies (Ek-Ramos et al. 2019).

Bacterial isolates that were positive for the features of PGP in vitro were used as inoculants in sweet sorghum. Twenty-eight days of the post-inoculation plants were harvested and measured for biometric parameters (Table 2). Sweet sorghum cv Numbu inoculated with endophytic bacterial isolate Paenibacillus sp. BB7, Bacillus sp. PIB1B, and Bacillus sp. PLB1B showed a significant difference compared to negative controls for stem length and dry weight of sweet sorghum. In the case of root length, the isolates of Paenibacillus sp. BB7 and Bacillus sp. PIB1B showed a significant difference from the negative control (Figure 2) but not for the plants inoculated with Bacillus sp. PLB1B, which did not give a significant 
difference from the negative control.

The isolation 16S rRNA gene with a size of $1500 \mathrm{bp}$ was successfully amplified from the DNA of potential endophytic bacterial isolates. The sequencing and analysis of the BLAST 16S rRNA gene showed that these endophytic bacteria belong to the phylum Alpha Proteobacteria (Devosia), Firmicutes (Bacillus, Paenibacillus, Staphylococcus), and Actinobacteria (Microbacterium, Brachybacterium). The phylogenetic tree analysis based on 16S rRNA gene sequences from isolates with PGP characteristics is displayed in Figure 3. The 16S rRNA gene sequence is stored in GenBank with the following accession numbers of MW666782, MW666784, MW667585, MW667586, MW683242, and MW683305. Bacteria from the genus Paenibacillus, Bacillus, Staphylococcus, and Microbacterium are endophytes in sweet sorghum plants (Mareque et al. 2015; de Fretes et al. 2018). Previous studies reported that bacteria from the genus Devosia were endophytes in the roots of Nitraria (Xu et al. 2017) and Brachybacterium were endophytes in rubber plants (Hidayati et al. 2014). The ability of endophytic bacteria as plant growth-promoting bacteria can support the growth of sweet sorghum as well as a solution to reduce the use of chemical fertilizers and pesticides.

\section{Conclusions}

In this study, the endophytic isolates have been proven for their great potential to promote plant growth based on several factors, including fixation of nitrogen, dissolution of phosphate, production of IAA and ACC deaminase, and antagonistic activity. Additionally, three endophytic bacterial isolates of Paenibacillus sp. BB7, Bacillus sp. PIB1B, and Bacillus sp. PLB1B demonstrates the ability in almost all tests and shows positive results for the growth of sweet sorghum plants. The study on growth-promoting microbial inoculants for growing sweet sorghum should be further studied. The particular strain may give great potential and commercial interest to produce inoculants for sweet sorghum cultivars.

\section{Authors' contributions}

CED, DW, YAP, TRN wrote the manuscript. CED, DW, YAP, TRN designed the study. CED was responsible for the overall stage of research. CED, DW, YAP, and TRN analyzed the data. All authors read and approved the final version of the manuscript.

\section{Competing interests}

The author declare that they have no competing interest.

\section{References}

Afifi MMI, El-Sayed GAM, Manal A, El-Gamal H, Massoud ON. 2014. Synergistic effect of biofertilizers containing $\mathrm{N}$-fixer, $\mathrm{P}$ and $\mathrm{K}$ solubilizers and humic substances on Sorghum bicolor productivity. Middle East J Appl Sci. 4(4):1065-1074.

Afzal I, Shinwari ZK, Sikandar S, Shahzad S. 2019. Plant beneficial endophytic bacteria: Mechanisms, diversity, host range and genetic determinants. Microbiol Res. 221:36-49. doi:10.1016/j.micres.2019.02.001.

Almodares A, Hadi MR. 2009. Production of bioethanol from sweet sorghum: A review. African J Agric Res. 4(9):772-780.

Behera BC, Yadav H, Singh SK, Mishra RR, Sethi BK, Dutta SK, Thatoi HN. 2017. Phosphate solubilization and acid phosphatase activity of Serratia sp. isolated from mangrove soil of Mahanadi river delta, Odisha, India. J Genet Eng Biotechnol. 15(1):169178. doi:10.1016/j.jgeb.2017.01.003.

Compant S, Clément C, Sessitsch A. 2010. Plant growth-promoting bacteria in the rhizo- and endosphere of plants: Their role, colonization, mechanisms involved and prospects for utilization. Soil Biol Biochem. 42(5):669-678. doi:10.1016/j.soilbio.2009.11.024.

Correa-Galeote D, Bedmar EJ, Arone GJ. 2018. Maize endophytic bacterial diversity as affected by soil cultivation history. Front Microbiol. 9(MAR). doi:10.3389/fmicb.2018.00484.

de Fretes CE, Suryani R, Purwestri YA, Nuringtyas TR, Widianto D. 2018. Diversity of endophytic bacteria in sweet sorghum (Sorghum bicolor (L.) Moench) and their potential for promoting plant growth. Indian J Sci Technol. 11(11):1-10. doi:10.17485/ijst/2018/v11i11/120283.

Duca D, Lorv J, Patten C, Rose D, Glick B. 2014. Microbial indole-3-acetic acid and plant growth. Anton Van Leeuwenhoek 106:85-125. doi:10.1007/s10482-0130095-y.

Ek-Ramos MJ, Gomez-Flores R, Orozco-Flores AA, Rodríguez-Padilla C, González-Ochoa G, TamezGuerra P. 2019. Bioactive products from plantendophytic Gram-positive bacteria. Front Microbiol. 10(MAR). doi:10.3389/fmicb.2019.00463.

Grönemeyer JL, Burbano CS, Hurek T, Reinhold-Hurek B. 2012. Isolation and characterization of rootassociated bacteria from agricultural crops in the Kavango region of Namibia. Plant Soil. 356(1-2):67-82. doi:10.1007/s11104-011-0798-7.

Gupta G, Parihar SS, Ahirwar KN, Snehi SK, Singh V. 2015. Plant Growth Promoting Rhizobacteria (PGPR): Current and Future Prospects for Development of Sustainable Agriculture. J Microb Biochem Technol. 07(02). doi:10.4172/1948-5948.1000188.

Gusti I, Mas A, Agung S, Ketut Sardiana I, Diara W, Made G, Nurjaya O. 2013. Adaptation, Biomass and Ethanol Yields of Sweet Sorghum (Sorghum bicolor (L.) Moench) Varieties at Dryland Farming Areas of Jimbaran Bali, Indonesia. J Biol Agric Healthc. 3(17):110-115. URL www.iiste.org.

Hallmann J, Quadt-Hallmann A, Mahaffee WF, Kloepper 
JW. 1997. Bacterial endophytes in agricultural crops. Can J Microbiol. 43(10):895-914. doi:10.1139/m97131.

Hardoim PR, van Overbeek LS, van Elsas JD. 2008. Properties of bacterial endophytes and their proposed role in plant growth. Trends Microbiol. 16(10):463-471. doi:10.1016/j.tim.2008.07.008.

Hayat R, Ali S, Amara U, Khalid R, Ahmed I. 2010. Soil beneficial bacteria and their role in plant growth promotion: A review. doi:10.1007/s13213-010-0117-1.

Hidayati U, Chaniago IA, Munif A, S, Santosa DA. 2014. Potency of Plant Growth Promoting Endophytic Bacteria from Rubber Plants (Hevea brasiliensis Mull. Arg.). J Agron. 13(3):147-152. doi:10.3923/ja.2014.147.152.

Jasim B, Jimtha John C, Shimil V, Jyothis M, Radhakrishnan EK. 2014a. Studies on the factors modulating indole-3-acetic acid production in endophytic bacterial isolates from Piper nigrum and molecular analysis of ipdc gene. J Appl Microbiol. 117(3):786-799. doi:10.1111/jam.12569.

Jasim B, Joseph AA, John CJ, Mathew J, Radhakrishnan EK. 2014b. Isolation and characterization of plant growth promoting endophytic bacteria from the rhizome of Zingiber officinale. 3 Biotech. 4(2):197-204. doi:10.1007/s13205-013-0143-3.

Mareque C, Taulé C, Beracochea M, Battistoni F. 2015. Isolation, characterization and plant growth promotion effects of putative bacterial endophytes associated with sweet sorghum (Sorghum bicolor (L) Moench). Ann Microbiol. 65(2):1057-1067. doi:10.1007/s13213-014-0951-7.

Olanrewaju OS, Glick BR, Babalola OO. 2017. Mechanisms of action of plant growth promoting bacteria. World J Microbiol Biotechnol. 33(11). doi:10.1007/s11274-017-2364-9.

Pretty J, Bharucha ZP. 2014. Sustainable intensification in agricultural systems. Ann Bot. 114(8):1571-1596. doi:10.1093/aob/mcu205.

Rosenblueth M, Martínez-Romero E. 2006. Bacterial endophytes and their interactions with hosts. Mol Plant-Microbe Interact. 19(8):827837. doi:10.1094/MPMI-19-0827.

Sansinenea E, Ortiz A. 2011. Secondary metabolites of soil Bacillus spp. Biotechnol Lett. 33(8):1523-1538. doi:10.1007/s10529-011-0617-5.

Santoyo G, Moreno-Hagelsieb G, del Carmen OrozcoMosqueda M, Glick BR. 2016. Plant growthpromoting bacterial endophytes. Microbiol Res. 183:92-99. doi:10.1016/j.micres.2015.11.008.

Sun Y, Cheng Z, Glick BR. 2009. The presence of a 1-aminocyclopropane-1-carboxylate (ACC) deaminase deletion mutation alters the physiology of the endophytic plant growth-promoting bacterium Burkholderia phytofirmans PsJN. FEMS Microbiol Lett. 296(1):131-136. doi:10.1111/j.15746968.2009.01625.X.

Vendan RT, Yu YJ, Lee SH, Rhee YH. 2010. Diversity of endophytic bacteria in ginseng and their potential for plant growth promotion. J Microbiol. 48(5):559-565. doi:10.1007/s12275-010-0082-1.

Xu L, Zhang Y, Read N, Liu S, Friman VP. 2017. Devosia nitraria sp. nov., a novel species isolated from the roots of Nitraria sibirica in China. Antonie van Leeuwenhoek, Int J Gen Mol Microbiol. 110(11):1475-1483. doi:10.1007/s10482-017-0901$\mathrm{z}$. 